\title{
Mouse-ear of Pecan: I. Symptomatology and Occurrence
}

\author{
Bruce W. Wood ${ }^{\mathbf{1}}$, Charles C. Reilly, and Andrew P. Nyczepir \\ U.S. Department of Agriculture, Agricultural Research Service, Southeastern \\ Fruit and Tree Nut Research Laboratory, Byron, GA 31008-0087
}

Additional index words. biennial bearing, flowering, profit, yields, production, stress, growth, nematodes, fungi, culture, phytohormones, copper, manganese, micronutrients, nitrogen, calcium

\begin{abstract}
Mouse-ear (ME) is a potentially severe anomalous growth disorder affecting young pecan [Carya illinoinensis (Wangenh.) K. Koch] trees in portions of the Gulf Coast Coastal Plain of the southeastern United States. A survey of its incidence and severity found it to be commonly exhibited by replants on second-generation orchard sites, or where mature pecan trees previously grew. While most frequently observed as a replant problem, it also occasionally occurs at sites where pecan has not previously grown. The disorder is not graft transmissible and is only temporarily mitigated by pruning. Degree of severity within the tree canopy typically increases with canopy height. Several morphological and physiological symptoms for mouse-ear are described. Important symptoms include dwarfing of tree organs, poorly developed root system, rosetting, delayed budbreak, loss of apical dominance, reduced photoassimilation, nutrient element imbalance in foliage, and increased water stress. The overall symptomatology is consistent with a physiological deficiency of a key micronutrient at budbreak, that is influenced by biotic (e.g., nematodes) and abiotic (e.g., water and fertility management strategies) factors. A comparison of orchard soil characteristics between ME and adjacent normal orchards indicated that severely affected orchards typically possessed high amounts of soil $\mathrm{Zn}, \mathrm{Ca}$, $\mathrm{Mg}$, and $\mathrm{P}$, but low $\mathrm{Cu}$ and $\mathrm{Ni}$; and were acidic and sandy in texture. The $\mathrm{Zn}$ : Cu ratio of soils appears to be a major factor contributing to symptoms, especially since ME severity increases as the $\mathrm{Zn}$ : $\mathrm{Cu}$ ratio increases. However, $\mathrm{Ni}$ may also be a factor as the $\mathrm{Zn}$ : $\mathrm{Ni}$ ratio is also larger in soils of ME sites. It is postulated that the "severe" form of mouseear is primarily due to the physiological deficiency of copper at budbreak, but may also be influenced by $\mathrm{Ni}$ and nematodes.
\end{abstract}

"Mouse-ear" (ME) is an abnormality of growth and development of pecan [Carya illinoinensis (Wangenh.) K. Koch]. Its incidence and severity have evolved from that of an occasional orchard curiosity in the early $20^{\text {th }}$ Century to that of a major contemporary problem in certain regions. The severe form of ME most commonly occurs in the southern Georgia sector of the U.S. pecan belt, but can also be found throughout much of the Gulf Coast Coastal Plain.

Originally termed "little-leaf," it was later termed "mouse-ear" by Blackmon and is typically identified by a leaflet deformity shaped to resemble the ear of a mouse (cited in Gammon and Sharpe, 1956). The slight to moderate forms of ME occur sporadically throughout the canopy and are often evident on only a single major limb, or even on a single terminal shoot. The anomaly first appears on the spring flush of shoots. It can consistently reappear from year to year, or appear only occasionally, on the same trees. Its occurrence is often spotty, and highly variable within affected trees and orchards. While symptomatology was briefly described by Gallaher and Jones (1976) and Gammon and Sharpe (1956) for the light to

Received for publication 27 Aug. 2002. Accepted for publication 13 Mar. 2003.

${ }^{1}$ To whom reprint requests should be sent. E-mail address: bwwood@saa.ars.usda.gov. moderate form of ME, there is need to expand the description so as to better understand the "severe" form of ME that is becoming increasingly common, and how it is controlled and prevented.

The anomaly was once suspected of being caused by a virus, then later attributed to being a nutritional disorder. A Cu deficiency was originally thought to be the cause, but $\mathrm{Cu}$ sprays to foliage and applications to the soil often did not correct ME (Gammon and Sharpe, 1956). It was later thought to be an Mn deficiency after leaves dipped in an $\mathrm{MnSO}_{4}$ solution, or when Mn applied to the soil around trees, occasionally appeared to correct symptoms (Gammon and Sharpe, 1956). In the case of potted seedlings, Goff and Keever (1991) and Keever et al. (1991) noted that it can be induced by application of $\mathrm{Ca}$, whereas Grauke et al. (1983) noted that it was associated with excessive N. It is uncertain that ME symptoms expressed on field trees is the same disorder, or has the same causal factors, as that of ME exhibited by potted seedlings (Grauke et al., 1983). To date, an effective and consistent control for ME has not been identified, nor has the cause been ascertained.

Eventual identification of the factor(s) causing mouse-ear, and the development of effective prevention or control strategies, potentially depends on gaining a better understanding of how ME affects the tree, where it occurs in orchards, and what is the cause(s). We therefore present: 1) refinements in morphological and physiological symptomatology; 2) greater insight into the conditions associated with occurrence; and 3) a hypothesis that a deficiency in physiologically available $\mathrm{Cu}$, at the time of budbreak, functions as the key cause of the "severe" form of mouse-ear commonly exhibited by recently transplanted pecan trees in southeastern orchards.

\section{Materials and Methods}

Study sites. Several ME-affected trees were studied in commercial orchards throughout the Gulf Coast Coastal Plain of Georgia. Soil types among affected orchards differed substantially, but were almost always either sandy loams or some sort of sands. Most ME-affected trees were found on sites previously supporting pecan orchards, or were replacement trees in existing mature orchards. However, MEaffected trees sometimes occurred on sites where pecan had not previously grown. In the latter case, these soils possessed low cation exchange capacities. Most of the affected cultivars were either 'Desirable' or 'Sumner', but also included 'Elliott' and 'Cape Fear', which are among the most commonly replanted cultivars in the southeastern United States. The rootstocks for these trees are unknown, but are likely either Curtis or Elliott seedlings.

Morphological symptoms. Tree organs and tissues were visually classified regarding MEassociated symptoms during early spring and midsummer of several years so as to identify specific symptoms. Affected trees were categorized according to degree of severity of ME symptoms. Two ME-based tree classes were studied (i.e., no ME symptoms vs. severe $\mathrm{ME})$. Trees of the two classes were randomly selected from five affected orchards. Ten trees of each treatment category in each orchard were evaluated for each parameter studied (i.e., trunk caliper, tree height, leaf area per shoot, nodes per shoot, shoot length, leaves per shoot, leaflets per leaf, and catkin length).

The root system of affected trees was evaluated by visual examination of lateral roots of pairs of adjacent trees (16 trees), with one exhibiting severe $\mathrm{ME}$ and the other free of symptoms. Roots were excavated within the uppermost $20 \mathrm{~cm}$ of the soil profile. Roots positioned on both the west and east side of the tree, but beneath the canopy, were measured for number of living secondary roots [i.e., the number of live laterals per linear $25 \mathrm{~cm}$ of $\operatorname{root}(<4 \mathrm{~mm}$ in diameter)]. Data were analyzed by analysis of variance (ANOVA) using SAS (SAS Institute, 1990).

Pattern within the canopy. The spatial distribution of ME was visually assessed as related to position within the canopy. Positional differences were assessed according to the condition of the five shoots displaying the most severe degree of $\mathrm{ME}$ within a designated vertical zone of the tree (from lowest to highest, $0 \%$ to $20 \%, 21 \%$ to $40 \%, 41 \%$ to $60 \%, 61 \%$ to $80 \%$, and $81 \%$ to $100 \%$ ). Severity classes were: $1=$ no ME, $2=$ trace $(<1 \%$ of foliage being distorted), $3=$ slight $(1 \%$ to $10 \%$ of foliage being distorted), $4=$ moderate $(11 \%$ to $50 \%$ 
being distorted), $5=$ heavy ( $51 \%$ to $100 \%$ being distorted), $6=$ very heavy ( $100 \%$ leaf distortion but no rosetting), and $7=$ severe (rosetting). Evaluations were based on 5 affected 'Desirable' trees between 4 and $12 \mathrm{~m}$ tall. Trees were from within a single orchard.

Graft transmissibility. ME-affected shoots were collected in early March, stored under refrigeration, and then grafted onto normal trees in early April. The graftwood was collected from six severely affected trees and grafted onto six normal trees via inlay bark grafts. Regrowth of grafts was then evaluated for ME symptoms as the shoots and leaves developed. Adjacent ME-affected shoots on trees from which the graftwood was obtained were observed for manifestation of ME so as to ensure that grafted shoots were indeed ME disposed.

Influence of pruning. About 35 'Desirable' trees were pruned by farmers at two orchards exhibiting severe ME. Trees were drip irrigated and commercially managed. Pruning was done during the dormant season by cutting several limbs back to $50 \%$ of their original length, but not all limbs within the trees were pruned. The severity of ME was observed on the pruned and nonpruned branches of trees the following 1-3 years, depending upon the orchard.

Physiological symptoms. Gas exchange activities of foliage were compared in July on fully expanded leaves of eight ME trees and eight adjacent normal trees. Gas exchange measurements were net photoassimilation(A), stomatal conductance ( $\mathrm{Sgw}$ ), and transpiration (E). Measurements were made using a LI-COR 6400 Photosynthetic System (LI-COR, Lincoln, Nebr.) on leaflets occupying the same relative position on the compound leaf and shoot of each of the two treatments. Sampled shoots were from the exterior and lower southern exposed portion of the canopy. Measurements on the ME-affected trees were from leaflets displaying heavy ME symptoms (Class-5 severity; as described above). The same leaflets were measured during mid-morning and again in mid-afternoon. Experimental design was a randomized complete block (eight blocks) with two ME treatments and two time-of-day treatments. Gas exchange treatments were made during mid-morning and mid-afternoon at $1800 \mu \mathrm{mol} \cdot \mathrm{s}^{-1} \cdot \mathrm{m}^{-2}$ photosynthetically active radiation according to previously reported methods for pecan (Wood et al., 2000). Leaf water potential was measured, on leaves at the same positions as described above, using a Scholander pressure bomb. Data were analyzed by ANOVA using SAS (SAS Institute, 1990).

Nutritional symptoms. Because affected trees typically exhibit various degrees of MEaffected foliage, depending upon the location of foliage within the canopy, determination of differences in nutrient element concentrations among $\mathrm{ME}$ and normal leaflets within the same tree were studied. ME-affected foliage was visually classified according to one of six categories based on severity. Severity was based on relative size of affected leaflets, degree of shape distortion, and amount of reduction in leaf growth. Categories were: $1=$ no abnormality; 2 = slight ME (slight rounding of leaflet tips); $3=$ light (pronounced rounding of leaflet tips); $4=$ moderate (obvious reduction in leaflet size); 5 = heavy (reduced leaflet size plus cupped margins); and $6=$ severe (reduced leaflet size, cupped margins, plus necrotic leaflet tips). Five trees were sampled in late April. All leaflets were removed from petioles of $\approx 20$ compound leaves reflecting each severity class. Leaflets were assessed for fresh weight, leaf area, dried at $55^{\circ} \mathrm{C}$, ground to pass a 20 -mesh screen, and submitted for elemental analysis by the Univ. of Georgia's Plant and Soil Analysis Laboratory using standard techniques. Nutrient element concentrations were regressed against ME severity using PROC-REG in SAS. Individual linear and multiple linear regressions were then calculated. We used the stepwise procedure for model selection. Nutrient elements were compared on a g-atom basis so as to provide greater greater resolution of how elements compare to each other.

Soil characteristics of sites with severely mouse-eared trees. Soils were collected from 15 Georgia orchards in which transplants exhibited severe ME. Soil was sampled from the top $18 \mathrm{~cm}$ of the soil profile beneath affected trees, for macro- and micronutrients concentrations, cation exchange capacity, and $\mathrm{pH}$. Orchards were segregated into three distinct classes; 1) "first generation" orchards (which had never before had pecan trees) showing ME; 2) "second generation" orchards (trees growing where there had previously been a pecan orchard or those situated where a large pecan tree has previously grown) showing ME; and 3) "first generation" orchards of young trees not showing ME symptoms, but adjacent to a second generation orchard showing symptoms in new transplants. The three orchard types were compared for statistical differences in nutrient elements by the Satterthwaite $t$ test (SAS Institute, 1990).

The rating for incidence of ME was done on trees of a 5-year-old drip-irrigated 'Desirable' orchard planted on a site that previously had $\approx 80$-year-old 'Success' trees. The previous 'Success' orchard had been commercially managed for several decades and had annually received soil fertilization and multiple annual foliar Zn sprays. The old 'Success' trees, planted on an $18.3 \times 18.3$-m spacing, were removed and new 'Desirable' trees (rootstock unknown) were transplanted at the exact positions of the previous tree as well as between previous tree sites (but in direction only), giving an $18.3 \times 9.15-\mathrm{m}$ spacing. Transplanted 'Desirable' trees began exhibiting ME symptoms the second and third year after planting. All trees were visually rated for ME symptoms (blunted foliage or resetting) during the 6th growing season. They were then mapped in relation to preexisting trees. Soil characteristics were then compared at sites between previously existing older trees. Soils at the two sites were sampled from 0 to $20 \mathrm{~cm}$ depths with a soil probe, with 10 subsamples bulked for each of 10 trees for each category. The experimental design consisted of two ME treatments and 10 replicates. Soil at the location of $10 \mathrm{ME}$ trees (beyond the auger hole, but within the canopy zone) was sampled at the $0-3 \mathrm{~cm}, 3.1-6 \mathrm{~cm}$, $6.1-9 \mathrm{~cm}, 9.1-15 \mathrm{~cm}$, and $15.1-20 \mathrm{~cm}$ depths for measurement of soil characteristics as performed at the Univ. of Georgia Plant and Soil Analysis Laboratory.

Influence ofold planting site. The incidence of ME was rated on trees of a 5-year-old dripirrigated 'Desirable' orchard planted on a site that previously supported a mature orchard of $\approx 80$-year-old 'Success' trees. The old 'Success' orchard had been commercially managed for several decades and had annually received fertilizer recommendations according to Georgia Extension Service guidelines. The preexisting 'Success' trees, planted on an $18.3 \times 18.3-\mathrm{m}$ spacing, were removed and 'Desirable' trees (rootstock unknown) were transplanted at the exact positions of the previously existing trees as well as midway between in one direction - giving an $18.3 \times 9.15$-m spaced orchard. Transplanted 'Desirable' trees exhibited ME symptoms the second and third year after planting. All trees were visually rated for ME symptoms (blunted foliage or rosetting) during the sixth growing season, and then mapped as related to the location of preexisting trees.

\section{Results and Discussion}

Morphological symptoms. Previously published reports describing the symptoms of ME have noted the ME-like distortion of foliage and dwarfed leaflets and leaves, but not other morphological symptoms exhibited by severely affected ME trees (Gallaher and Jones, 1976; Grauke et al., 1983; Worley, 1979). Several distinct symptoms of the severe form of ME are illustrated in Fig. 1.

Figure 1A illustrates some of the most common morphs expressed by ME foliage. Compound leaves and leaflets can be reduced in size to $<1 \%$ of normal foliage. Moderate to severe cases of ME typically exhibit some degree of rosetting at shoot tips (Fig. 1B). Rosetting sometimes results after death of the terminal bud, but also commonly occurs without terminal bud death. In severe cases, primary, secondary, and tertiary buds simultaneously break at shoot nodes (Fig. 1C). Shoots are usually dwarfed, spindly, brittle, and have abnormally elongated and pointed buds (Fig. 1D). ME shoots have shorter internodes, but a similar number of nodes compared to normal shoots, causing affected shoots to be dwarfed (Fig. 1E). Shoots also exhibit delayed budbreak (Fig. 1F), up to 3 weeks. Catkins are also substantially reduced in length and often display necrotic tips (Fig. 1G).

Other symptoms associated with severe ME that have not been previously reported include: 1) necrosis of the apical tips of leaflets; 2) a small zone adjacent to this necrotic region that is dark green during the early stages of ME; 3 ) leaflets that are more chlorotic during the first few weeks after budbreak than normal leaves of equal age, but usually becoming equally green by midsummer; 4) the base of the petiole of the compound leaf of affected leaves often exhibits a distortion of growth to produce a wing-like protrusion along both sides of the basal section of the petiole; 5) leaflet margins are curled and 


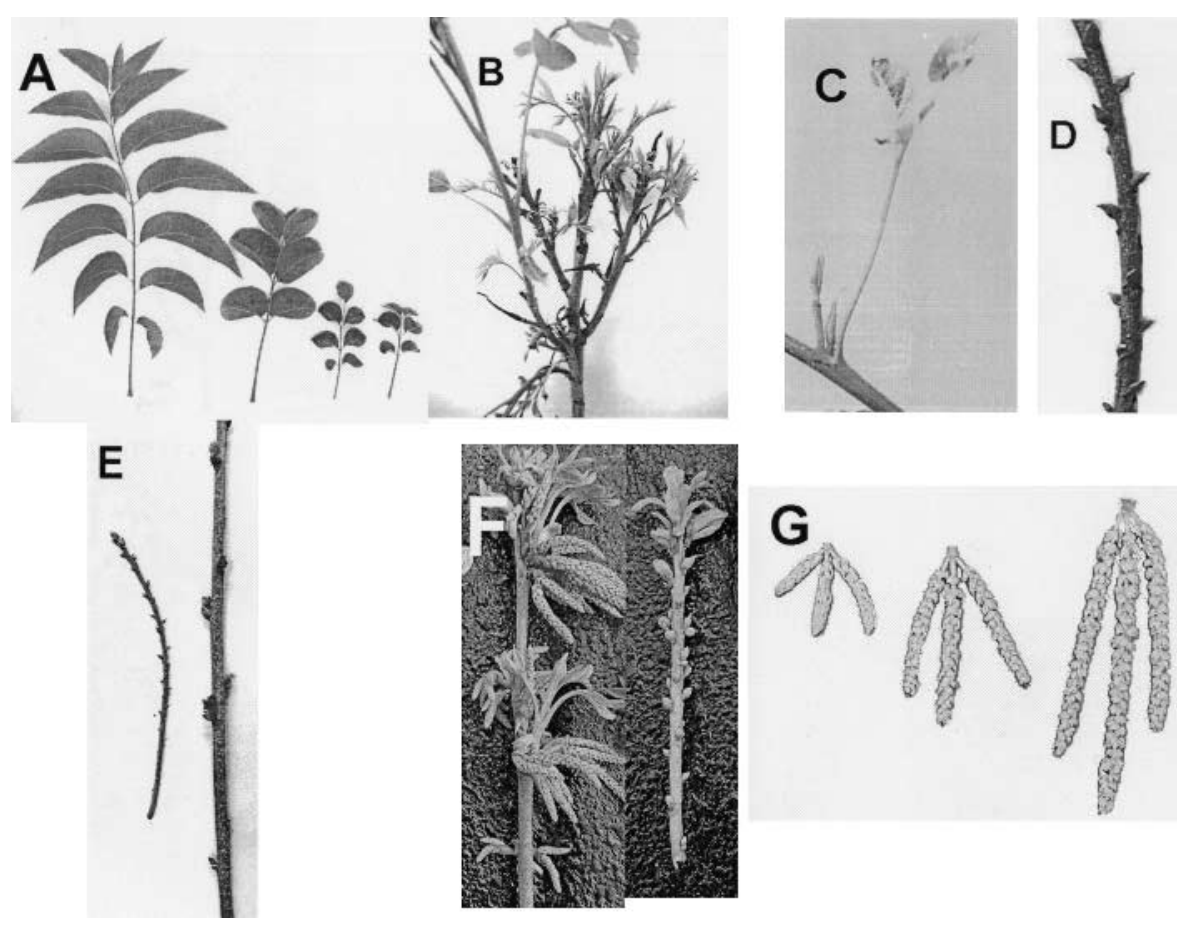

Fig. 1. Characteristics of severe mouse-ear: (A) Mouse-ear-like shaped foliage; $(\mathbf{B})$ rosetting $(\mathbf{C})$ budbreak of multiple buds on one-year-old shoots; (D) elongated and pointed buds; (E) dwarfed shoots; $(\mathbf{F})$ delayed budbreak; and (G) dwarfed catkins. shoot. Average catkin length was $\approx 67 \%$ that of the lamina is wrinkled and brittle; 6) shoots often die during the dormant season, thus giving the appearance of cold injury; 7) trees are dwarfed; 8) there are few catkins on affected shoots and almost no pistillate flowers; 9) in the most severe cases the lamina of leaflets fails to form and the associated emerging shoot dies; 10) the root system of severely affected trees is reduced, exhibiting relatively few "feeder" and lateral roots [a similar reduction in root growth by ME trees was reported by Grauke et al., (1983) for potted seedling trees.]; and 11 ) tree death (estimated to occur in $\approx 0.5 \%$ of the ME cases).

The 18-year-old 'Desirable' trees that exhibited severe ME had several significant growth differences compared to normal trees (Table 1). Mouse-eared trees were about onethird the height and caliper of adjacent normal trees (Table 1). Shoots of mouse-eared trees had about $11 \%$ of the leaf area on affected shoots as did normal trees, although the number of leaves per shoot and leaflets per compound leaf were equal. Mouse-eared shoots were much shorter ( $\approx 26 \%$ of normal length) than normal shoots, but did not differ in the number of nodes per normal catkins. Mouse-eared trees also exhibited only $19 \%$ as many living roots branching from primary lateral roots. Excavated roots sys-

Table 1. Influence of mouse-ear on morphological and growth characteristics of 'Desirable' pecan trees.

\begin{tabular}{lccccccccc}
\hline & $\begin{array}{c}\text { Tree } \\
\text { height } \\
\text { Tree }\end{array}$ & $\begin{array}{c}\text { Tree } \\
\text { caliper } \\
(\mathrm{m})\end{array}$ & $\begin{array}{c}\text { Shoot } \\
\text { leaf area } \\
\left(\mathrm{cm}^{2}\right)\end{array}$ & $\begin{array}{c}\text { Shoot } \\
\text { length } \\
(\mathrm{cm})\end{array}$ & $\begin{array}{c}\text { Nodes } \\
\text { per shoot } \\
(\text { no. })\end{array}$ & $\begin{array}{c}\text { Leaves } \\
\text { per shoot } \\
(\text { no. })\end{array}$ & $\begin{array}{c}\text { Leaflets } \\
\text { per leaf } \\
(\text { no. })\end{array}$ & $\begin{array}{c}\text { Catkin } \\
\text { length } \\
(\mathrm{cm})\end{array}$ & $\begin{array}{c}\text { Live lateral } \\
\text { roots per } \\
\text { decimeter } \\
(\text { no. })\end{array}$ \\
\hline Normal & 6.2 & 27.5 & 1,620 & 81 & 31 & 9 & 11 & 9 & 6 \\
Mouse-ear & 2.4 & 9.5 & 78 & 21 & 29 & 9 & 11 & 6 & 1 \\
Significance $^{\mathrm{z}}$ & $*$ & $*$ & $*$ & $*$ & NS & NS & Ns & $*$ & $*$ \\
\hline
\end{tabular}

Ns, * Nonsignificant or significant at $P \leq 0.05$, respectively.

tems of ME-affected trees typically exhibited considerable numbers of dead roots $(>75 \%$ in cases of more severe ME). Thus, mouse-eared trees were generally dwarfed and had impaired root system of fewer living lateral roots per tree. Such an impairment of root growth has been reported to be an effect of Cu deficiency in wheat (Graham, 1981).

While several of the above-described symptoms may be characteristic of certain deficiencies or toxicities of any one of several nutrient to those reported for $\mathrm{Cu}$ deficiency on citrus crops in sandy Florida soils (Reuther, 1957). The relatively sandy, low cation exchange capacity, soils of the Atlantic Coastal Plains typically contain low levels of native copper (Reuther, 1957), and citrus orchards growing on such soils often exhibited $\mathrm{Cu}$ deficiency symptoms. Symptoms common between $\mathrm{Cu}$ deficiency in Florida citrus and ME in pecan in Georgia are 1) short internodes; 2) twig dieback; 3) multiple buds breaking at nodes; 4) rosetting; 5) malformation of leaves; 6) chlorosis of foliage; and 7) marginal necrosis at leaf tips. $\mathrm{Cu}$ deficiency is often highly variable in orchards, resulting in a spotty display of symptoms, especially in low cation exchange capacity soils (Robson and Reuter, 1981). The effect of $\mathrm{Cu}$ deficiency on decreasing

HortScience, Vol. 39(1), February 2004 elements, some of these symptoms are similar lignification of shoots (Robson and Reuter, 1981), and the brittle shoots noted on severely ME-affected trees, also provides evidence for the involvement of $\mathrm{Cu}$. Thus, circumstantial evidence indicates that the severe form of $\mathrm{ME}$ may be due, at least in part, to a physiological deficiency of $\mathrm{Cu}$, as was noted early in the 20 th century, but later discounted by Gammon and Sharpe (1956) in favor of a hypothesis for Mn deficiency.

The above-mentioned dwarfing of various organs (shoots, foliage, catkins), delayed budbreak, and rosetting indicates a disruption in growth regulator physiology. The loss of apical dominance associated with rosetting, delayed budbreak, and loss of correlative inhibition of secondary and tertiary buds at shoot nodes is evidence that endogenous auxin physiology is adversely affected. The dwarfing of various organs is circumstantial evidence that gibberellin physiology may also be affected by whatever is causing ME. It is noteworthy that one or more $\mathrm{Cu}$-enzymes may potentially play a key role in hormonal synthesis and metabolism, can also influence auxin physiology (Takahama and Takayuki, 1994), and are important in cellular and tissue development when organs are young (Walker and Webb, 1981). It is also noteworthy that $\mathrm{Mn}$ is critical to the activation of enzymes in the biosynthetic pathway for gibberellins and the potential for competitive inhibition of key enzymes (kaurene synthetase or those involved in the conversion of geranylgeranyl phrophosphate to ent-kaurene) by certain other transition elements ( $\mathrm{Fe}$ ions have almost the same ionic radius as $\mathrm{Mn}$ ions and share some of the same valance states, thus Fe might potentially bind with key enzymes) (Hedden et al., 1978; Rappaport and Adams, 1978).

The above-described symptoms appear to be consistent with the hypothesis that severe $\mathrm{ME}$ is primarily due to a physiological deficiency of $\mathrm{Cu}$ during the early stages of shoot and leaf development at budbreak and shortly thereafter.

Pattern within the canopy. In the case of young trees exhibiting only a slight amount of ME-like distortions in leaf morphology, the distortion appears at random within the canopy. It can be associated with a pair of leaflets, a single compound leaf, a single shoot, or a single limb. However, in the case of moderate to severe ME, foliar symptoms consistently vary in degree of severity according to canopy position. Gradations in degree of severity within trees of the above-described study was such that severity class of ME symptoms increased linearly $(y=2.21+0.87 x ; P<$ $\left.0.0001, r^{2}=0.60\right)$ with distance of canopy from the orchard floor (Fig. 2). Foliage and shoots of the upper canopy of moderate to severely affected trees ranged from heavy to severe in the upper $20 \%$ of the canopy, whereas the lower $20 \%$ exhibited only slight to moderate severity. Alinear $(y=6.60-0.53 x ; P<0.0001$, $\left.r^{2}=0.65\right)$ gradient in severity is also evident in the compound leaves on affected shoots, in that severity is typically most pronounced on the basal compound leaves of shoots (data not shown). The apical compound leaf often 
exhibits only moderate to slight ME distortions in shape of associated leaflets, whereas the basal-most leaves exhibited moderate to severe ME. Similarly, the basal-most leaflet pairs of each compound leaf tends to exhibit a much greater severity of distorted leaflets than apical-most leaflet pairs (Fig. 1A).

The above-described gradients in severity of ME within canopy, shoots, and compound leaves indicate that the symptom was associated with a deficiency of some factor, presumably one or more micronutrients, that was limiting at the time of budbreak and during the early stages of shoot and foliage development, but because nonlimiting or less limiting within a few days or weeks after the initiation of shoot and foliar growth. This indicates that the factor(s) is not stored in sufficient accessible quantities from the previous growing season; thus, failing to satisfy demands associated with following Spring's shoot and leaf growth until there has been ample root uptake and translocation to the developing shoot and leaves. Thus, the factor(s) does not readily translocate from senescent foliage into bud or shoot storage pools for next season's growth processes. This characteristic fits the relatively limited mobilization ability of certain metallic cation trace elements $(\mathrm{Cu}$, $\mathrm{Mn}, \mathrm{Fe}, \mathrm{Zn}, \mathrm{Co}, \mathrm{Ni}$, Ti, and V) as compared to readily translocatable metallic cations $(\mathrm{K}$, $\mathrm{Mg}$, and Ca) (Tisdale et al., 1992). Of these essential, or beneficial, micronutrients, it is $\mathrm{Cu}$ that is generally regarded as most limited in its retranslocatability from fall foliage to storage pools (Kochian, 1991; Robson and Reuter, 1981; Welch, 1995).
The role of a micronutrient as the causal factor is further supported by the fact that severity of ME in canopies substantially increases with tree height. Due to hydraulic resistance, evapotranspiration driven transport of xylem contents to the tallest portion of the tree is usually less than to portions closer to the root system. Thus, the upper canopy is subject to receiving less of the xylem mobile micronutrients during the early portion of shoot and leaf development. This is why the most pronounced micronutrient deficiency in pecan - zinc deficiency - is more noticeable and most severe at the tree top. This characteristic of a micronutrient deficiency is likely to be the most pronounced in early spring when root system uptake is substantially limited by either low elemental availability, low soil cation exchange capacity, or by a root system possessing diminished absorption capacity.

The bottom to top of canopy gradient in severity of ME, plus the expression of symptoms at the earliest stages of budbreak, is also evidence that micronutrients are not reaching the breaking buds via xylem sap and are limiting normal tissue development. This reduced availability of micronutrients could be due to several factors, including: 1 ) dilution by growing points, 2) adsorption to xylem cell walls, or 3 ) both dilution and adsorption. As a ringporous species, the cambium of pecan becomes active almost simultaneously throughout the tree prior to budbreak (as evidenced by the slippage of bark), meaning that newly formed xylem vessels are already functional prior to budbreak (Zimmermann and Brown, 1971). These new cell walls provide a formidable

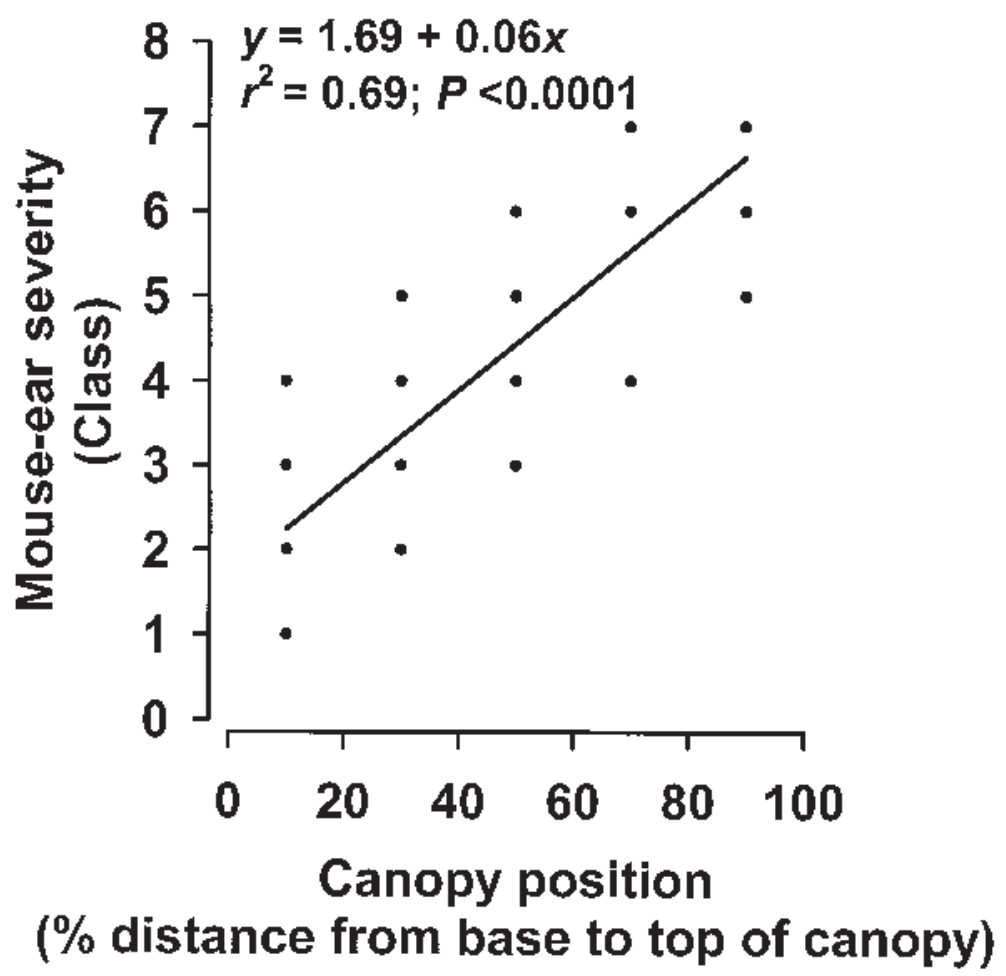

Fig. 2. The relationship of degree of severity of mouse-ear (ME) to general location of foliage within the canopy of trees (between 4 and $12 \mathrm{~m}$ tall) is illustrated. Severity classes were: $1=$ no ME; $2=$ trace $(<1 \%$ of foliage being distorted); $3=$ slight $(1 \%$ to $10 \%$ of foliage being distorted); $4=$ moderate ( $11 \%$ to $50 \%$ being distorted); $5=$ heavy $(51 \%$ to $100 \%$ being distorted); $6=$ very heavy $(100 \%$ leaf distortion but no rosetting); and $7=$ severe (rosetting). barrier to the translocation of certain metallic micronutrients, because of adsorption of cations to newly formed cell wall proteins, (Walker and Webb, 1981). Of all the known metallic cation essential micronutrients, $\mathrm{Cu}$ is most prone to adsorption by xylem cell walls (Walker and Webb, 1981). Once Cu is adsorbed on the xylem cell wall, it is not easily desorbed, and is therefore unavailable for physiological processes (Harrison et al., 1979). Therefore, $\mathrm{Cu}$ is the xylem mobile essential micronutrient that is likely to be most limiting at budbreak. The above-mentioned observations provide circumstantial evidence consistent with the hypothesis that a deficiency of essential micronutrient(s) - most likely $\mathrm{Cu}$ - plays a key role in the cause of the severe form of ME.

Graft transmissibility. When shoots exhibiting severe ME symptoms were grafted to normal trees, the developing organs of the graft on the stock never exhibited ME symptoms (data not shown) whereas adjacent shoots on the donor trees always showed ME the next spring. These grafts did not revert to exhibit ME symptoms within three years of grafting, nor did symptoms appear on other portions of the stock. Thus, ME was not transmitted via grafting and was rapidly and totally cured with access to the vascular system of the healthy host tree.

This response is evidence that $\mathrm{ME}$ is not due to a shoot associated infection of a biological agent, such as a virus, bacterium, mycoplasma, or fungus. Exposure to the host tree's vascular system appears to have provided one or more factors that enabled predisposed ME buds to grow normally.

These results indicate that the proposed essential micronutrient deficiency within the buds of the ME grafts was corrected at, or soon after, the time of budbreak. This is consistent with the hypothesis that severe ME is caused by a localized physiological deficiency of one or more micronutrients at the time of budbreak. It also is consistent with the expectation that xylem cell wall adhering micronutrients, such as $\mathrm{Cu}$, would become less limiting in xylem sap, because of the likelihood of fewer adsorption sites, by the time buds of the grafted shoots broke 3 to 4 weeks after the normal time of budbreak in the host tree.

Influence of pruning. Pruned limbs of severely ME affected trees broke bud from 1-3 weeks later than did buds from nonpruned limbs (anecdotal observations only). Shoots and foliage produced the first growing season after pruning exhibited little or no ME, whereas the nonpruned limbs exhibited substantial levels of ME. However, growth from the pruned limbs the second and third year after pruning once again exhibited severe ME similar to that exhibited on nonpruned limbs. Thus, pruned trees eventually reverted to displaying ME.

This anecdotal observation is consistent with the results from the above-described grafting study in that buds breaking later than normal in the Spring, show little or no ME symptoms. The same effect was also noted for second-cycle shoots breaking bud in $\mathrm{Au}-$ gust-i.e., no mouse-ear was ever visible on late season shoots. It is also noteworthy that 
when ME is so severe that the primary buds die, or the resulting shoots abort soon after budbreak, the resulting secondary or tertiary buds result in normal or near normal shoot and foliar growth and development. This indicates that the limiting factor(s) has become nonlimiting, or nearly so, by the time of this secondary phase of budbreak. These observations are consistent with the above-described expectation that xylem cell wall adhering micronutrients, such as $\mathrm{Cu}$, would become less limiting in xylem sap as the growing season progresses, because of the likelihood of fewer adsorption sites. Thus, by the time buds of the pruned or second-cycle shoots broke, the micronutrient was no longer physiologically limiting. These results are therefore consistent with an early season deficiency of $\mathrm{Cu}$.

Physiological symptoms. The ME-affected trees differed from adjacent normal trees in rate of gas exchange for both $\mathrm{CO}_{2}$ and $\mathrm{H}_{2} \mathrm{O}$ (Fig. 3). The rate of $\mathrm{A}$ for similar leaflets, between $\mathrm{ME}$ and control trees, was affected by both ME and time of day (Fig. 3A). Based on equivalent leaf areas, ME-affected leaflets were only $63 \%$ as productive during midmorning hours as were unaffected leaflets. During the afternoon hours, ME-affected leaves were only $26 \%$ as productive as were unaffected leaflets. Both ME and unaffected leaflets exhibited substantially lower A in the afternoon as compared to midmorning. ME and timeof-day treatments interacted to result in the percentage of reduction in the afternoon being greater for the ME trees than for the control trees $79 \%$ of morning rates for the control and $32 \%$ for the ME-affected trees). Stomatal conductance (Sgw) of similar leaflets of $\mathrm{ME}$ trees was $\approx 68 \%$ of the control at either midmorning or mid-afternoon (Fig. 3B). Sgw for both treatments was less during the afternoon than in midmorning.

Although leaflet color was not measured, visual observation clearly indicated that affected leaflets, as compared to normal leaflets, are initially more yellowish green within the first 2 to 6 weeks after budbreak and become darker green by mid-June to July. In certain cases, severely ME-affected foliage can appear to be darker green than do normal foliage when viewed in mid- to late summer. The abovedescribed measurements of gas exchange were done when ME affected foliage did not appear to differ in color from normal foliage.

ME-affected trees also differed from adjacent normal trees in water relations characteristics. Transpiration was greater in normal than in ME-affected foliage, with $\mathrm{E}$ being greater in the afternoon than in the morning (Fig. 3C). Leaf water potential also differed between the ME and normal leaves (Fig. 3D) in the afternoon. ME affected foliage exhibited higher $\Psi \omega$ than did normal leaves in the afternoon but not in the morning. Afternoon $\Psi \omega$ was greater than morning $\Psi \omega$ for both normal and ME leaves.

These measures of $\mathrm{CO}_{2}$ and $\mathrm{H}_{2} \mathrm{O}$ exchange rates and $\Psi \omega$ indicate that $\mathrm{ME}$-affected trees exhibit reduced rates of net photosynthesis and are also under greater water stress than normal trees. This undoubtedly contributes to
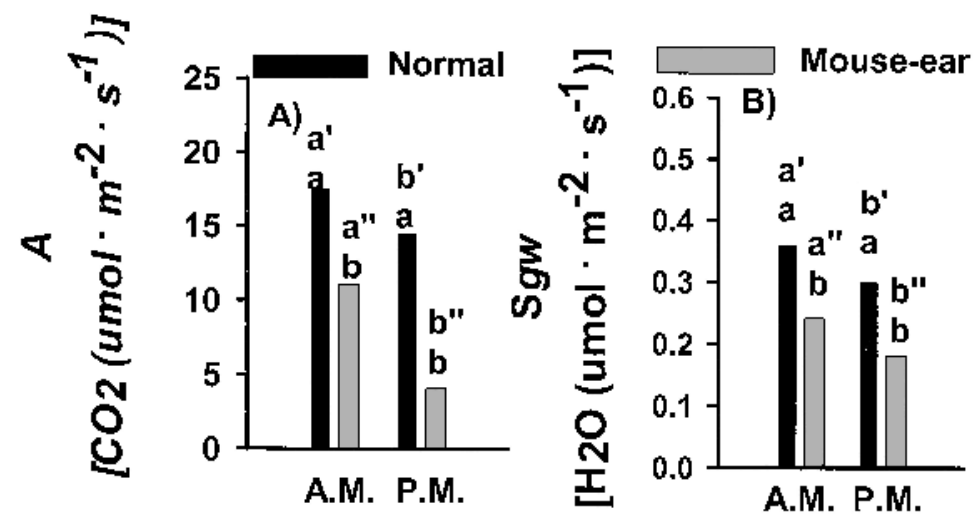

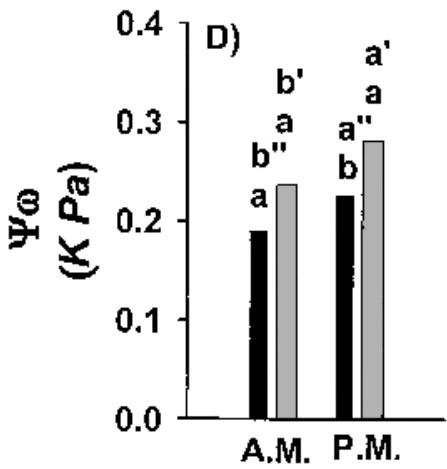

Time of day

Fig. 3. Comparison of mouse-eared and normal trees, during midmorning and midafternoon, for photoassimilation $(A)$, stomatal conductance $(\mathrm{Sgw})$, leaf transpiration $(E)$, and leaf water potential $(\Psi \omega)$. Differences in treatment means are identified by $t$ tests $(P \leq 0.05)$ with differences noted by different letters [i.e., comparisons are mouse-ear A.M. vs. normal A.M. (a and b denote statistical differences), mouse-ear P.M. vs. normal P.M. (a and b denote differences), mouse-ear A.M. vs. mouse-ear P.M. ( $\mathrm{a}^{\prime}$ and $\mathrm{b}^{\prime}$ denote differences), and normal A.M. vs. normal P.M. (a" and b" denote differences)].

the reduced tree height, trunk diameter, and shoot length so typical of severely affected trees (Table 1). The greater water stress in affected trees, and the associated reduction in transpiration, implies that affected trees are less able to move xylem mobile micronutrients in the transpirational stream to developing buds, shoots, and leaf tissues, especially those tissues at the top of the tree. This is consistent with the above-described observation that, in cases of severely affected trees, the severity of ME increases with increasing tree height (Fig. 2). The ME-associated reduction in A indicates that possibly $\mathrm{Cu}, \mathrm{Fe}$, or $\mathrm{Mn}$ could be involved because of their key roles in photosynthetic electron transport (Welch, 1995). These observations are also consistent with the hypothesis that $\mathrm{ME}$ is due to a localized physiological deficiency of one or more micronutrients at the time of budbreak.

Nutritional symptoms. The level of several macro- and micronutrients in late April leaflets varied with ME severity class (Fig. 4). Linear regression analysis of g-atom leaf elemental concentrations against severity level of ME, indicated increases in severity as $\mathrm{P}\left(r^{2}=0.61\right)$, $\mathrm{Al}\left(r^{2}=0.72\right), \mathrm{Zn}\left(r^{2}=0.68\right), \mathrm{Fe}\left(r^{2}=0.84\right)$, $\mathrm{Na}\left(r^{2}=0.39\right)$, and $\mathrm{B}\left(r^{2}=0.62\right)$ increased; and an inverse relationship with $\mathrm{Ca}\left(r^{2}=0.54\right)$ and $\mathrm{Cu}\left(r^{2}=0.48\right)$. The associations with $\mathrm{N}$,
$\mathrm{K}, \mathrm{Mg}, \mathrm{Fe}$, and $\mathrm{Mn}$ exhibited $r^{2}$ values $<0.35$ and were nonsignificant at $P \leq 0.05$. The best stepwise multiple linear regression model was: $\mathrm{ME}$ rating $=-7.39+24 * \mathrm{P}+1,979 * \mathrm{~B}+$ $981 * \mathrm{Na}, R^{2}=0.96$; with $\mathrm{Fe}$ being added first, $\mathrm{P}$ second, $\mathrm{B}$ third, $\mathrm{Na}$ fourth, and $\mathrm{Fe}$ removed in the presence of the other three. This indicates that there are major changes in levels of certain nutrients as severity of ME increases. Levels of $\mathrm{P}, \mathrm{B}$, and $\mathrm{Na}$ possess the greatest predictive power, but the nature of this study does not allow for discrimination as to whether these elements are involved in the induction of the various severity levels of ME or are the result of ME.

These data therefore raise the possibility that one or more elements $(\mathrm{P}, \mathrm{B}, \mathrm{Na}, \mathrm{Al}, \mathrm{Zn}, \mathrm{Fe})$ are involved in ME because their concentrations were proportional to increasing severity of ME symptoms. It also opens up a similar inverse possibility for $\mathrm{Ca}$ and $\mathrm{Cu}$. Yet, foliar nutrient levels for all elements measured were within the sufficiency range for pecan B, i.e., no toxicities or deficiencies when assessed at their absolute levels within the foliage (O'Barr, 1989). In light of evidence presented earlier in this article, it is likely that the linkage between the concentrations of these elements and severity of ME is one of "effect" rather than of "cause," with $\mathrm{Cu}$ being a possible exception 


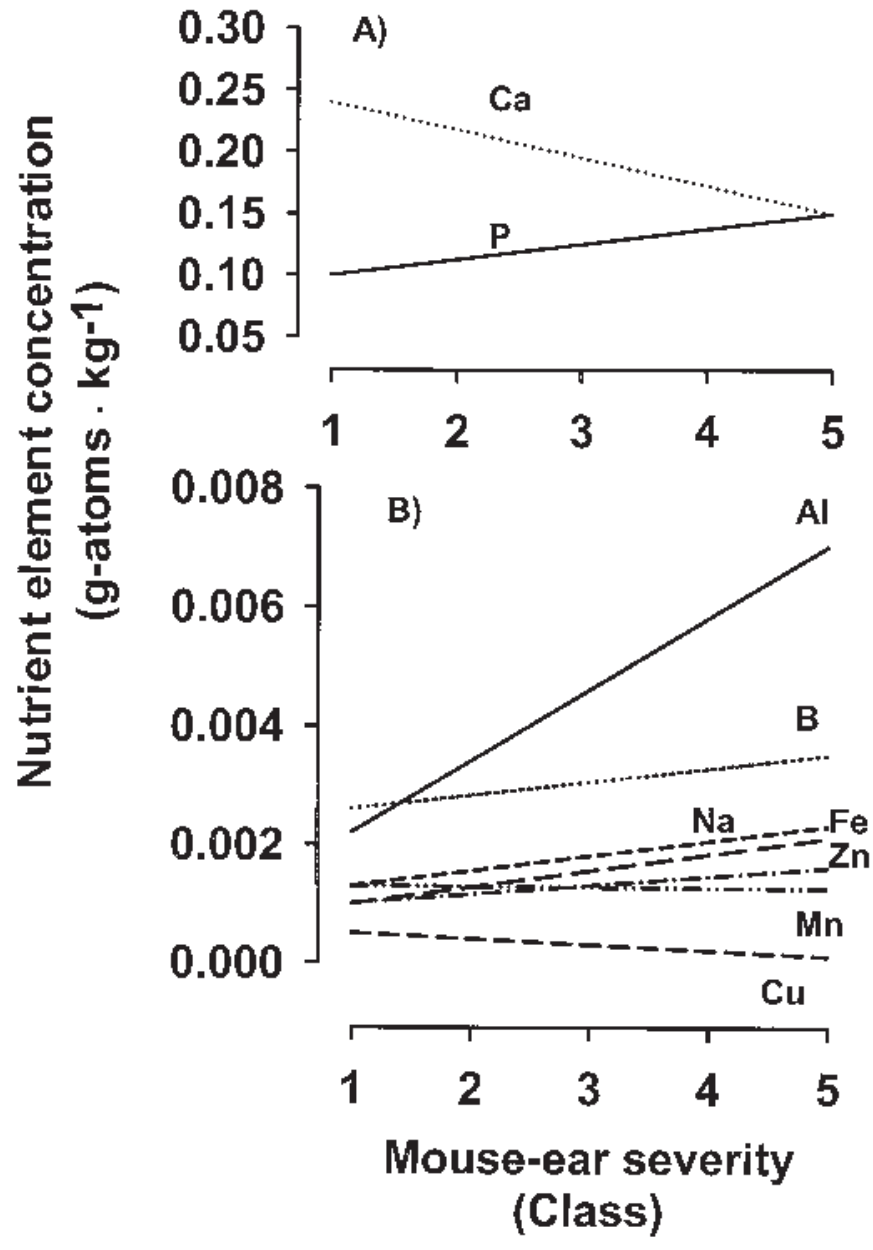

Fig. 4. Linear regressions of relationship between severity classes of mouse-ear, on the same affected tree during the early stage of mouse-ear development (April), and g-atom concentrations of nutrient elements in developing foliage. The correlation with $\mathrm{N}, \mathrm{K}, \mathrm{Mg}, \mathrm{Fe}, \mathrm{Cu}$, and $\mathrm{Mn}$ exhibited $r^{2}$ values $<0.35$ and were nonsignificant at $P \leq 0.05$, whereas the significant associations were as follows: $\mathrm{P}\left(r^{2}=0.61\right) ; \mathrm{Al}\left(r^{2}=0.72\right) ; \mathrm{Zn}\left(r^{2}=0.68\right) ; \mathrm{Fe}\left(r^{2}=0.84\right) ; \mathrm{Na}\left(r^{2}=0.39\right) ;$ and $\mathrm{B}\left(r^{2}=0.62\right)$ increased with severity of mouse-ear and $\mathrm{Ca}\left(r^{2}=0.54\right)$ and $\mathrm{Cu}\left(r^{2}=0.48\right)$ decreased with severity of mouse-ear. The statistically significant macronutrients are in $(\mathbf{A})$ and the micronutrients are in $(\mathbf{B})$.

due to the tendency for $\mathrm{Cu}$ to physiologically unavailable at budbreak.

Although, there was no detectable relationship between the severity of ME and most of the measured micronutrients, these data do not exclude the possibility that one or more micronutrients are in the foliage at insufficient levels, and are physiologically limiting due to being tied up in unavailable organic complexes. These results are still consistent with the hypothesis that ME is due to a localized physiological deficiency of one or more micronutrients at the time of budbreak, but suggests that this deficiency may be associated with the micronutrient(s) being tied up in physiologically unavailable forms rather than a deficiency in the absolute amount of the micronutrient(s). Because of the often poor relationship between the absolute amount of $\mathrm{Cu}$ in foliar tissues and physiologically available forms of $\mathrm{Cu}$, the foliar concentration of $\mathrm{Cu}$, as measured by standard pecan leaf analysis, may be useless from the standpoint of ascertaining actual $\mathrm{Cu}$ status within the context of tree physiological needs (Walker and Webb, 1981). Thus, Cu behavior in plants is consistent with the results of this analysis of ME affected foliage.

Soil characteristics of sites with severely mouse-eared trees as compared to adjacent sites without ME. Soils supporting trees exhibiting severe $\mathrm{ME}$ were on acidic ( $\mathrm{pH}$ ranging from 5.2 to 6.9 ), low cation exchange capacity (4.4 to $12.5 \mathrm{meq} / 100 \mathrm{~g}$ ) soils that were also sandy textured (i.e., loamy sand or sandy loam) (Table 2). First generation orchards exhibiting ME had higher amounts of $\mathrm{P}$ and $\mathrm{Zn}$, but did not differ in $\mathrm{pH}, \mathrm{CEC}, \mathrm{K}$, $\mathrm{Mg}, \mathrm{Ca}, \mathrm{Mn}, \mathrm{Fe}, \mathrm{Cu}, \mathrm{B}, \mathrm{Ni}, \mathrm{Co}$, or $\mathrm{Sn}$, than first generation orchards that did not exhibit ME and were adjacent to second generation orchards exhibiting ME (Table 2). Similarly, second generation orchards exhibiting ME had higher amounts of $\mathrm{P}, \mathrm{Mn}, \mathrm{Fe}, \mathrm{Zn}, \mathrm{Cu}, \mathrm{Ni}$, and $\mathrm{Sn}$, but did not differ in $\mathrm{pH}, \mathrm{CEC}, \mathrm{K}, \mathrm{Mg}, \mathrm{Ca}$, $\mathrm{B}$ or $\mathrm{Co}$, than first generation orchards that did not exhibit ME (and were adjacent to second generation orchards exhibiting ME) (Table 2). First generation orchard sites exhibiting ME had less $\mathrm{Mn}, \mathrm{Zn}, \mathrm{Cu}, \mathrm{Ni}$ and $\mathrm{Sn}$, than second generation sites showing ME. Thus, higher $\mathrm{P}$ and $\mathrm{Zn}$ levels are evident in soils of orchards that exhibit ME and second generation orchard soils appear to have accumulated $\mathrm{Zn}, \mathrm{Mn}, \mathrm{Cu}$, $\mathrm{Ni}$, and $\mathrm{Sn}$ over decades of orchard management for nutritional and disease control issues. Soil test reports for second-generation orchards almost always classified $\mathrm{P}, \mathrm{Ca}, \mathrm{Mg}$, and $\mathrm{Zn}$ amounts as "very high."

When these three types of orchards were compared with regard to ratios of certain micronutrients to $\mathrm{Cu}$, it was found that the soil $\mathrm{Zn}$ : $\mathrm{Cu}$ ratio (g-atoms per unit of cation exchange capacity) of the soil was $\approx 16$ - to 17 fold greater in the two types of ME-affected orchards as compared to adjacent non-mouseeared orchard soils (Table 3 ). There were no differences in the $\mathrm{Co}: \mathrm{Cu}, \mathrm{Mn}: \mathrm{Cu}$; and $\mathrm{Sn}: \mathrm{Cu}$ ratios. Second generation orchards possessing $\mathrm{ME}$ also had a $\mathrm{Ni}: \mathrm{Cu}$ ratio of $\approx 9$-fold that of first generation ME orchards. Similarly, the $\mathrm{Zn}$ : Ni ratio in these three orchards was such that there was 34 times as much $\mathrm{Zn}$ as $\mathrm{Ni}$ in the first generation mouse-eared orchard and 11 times more in the second generation ME orchard (Table 3). These observations provide additional evidence that low soil $\mathrm{Cu}$ (and possibly $\mathrm{Ni}$ ), and the problem is exacerbated by high soil $\mathrm{Zn}$, is involved in ME.

The low level of $\mathrm{Cu}$ in these soils is consistent with the hypothesis that $\mathrm{Cu}$ deficiency was a key cause of the severe form of ME. Other factors potentially limiting the uptake of $\mathrm{Cu}$ from these low $\mathrm{Cu}$ soils is the high soil levels of $\mathrm{Zn}, \mathrm{P}$, and $\mathrm{Ca}$ that is typical for these

Table 2. Comparison of soil characteristics between orchards exhibiting mouse-ear (ME) and adjacent orchards not exhibiting ME.

\begin{tabular}{|c|c|c|c|c|c|c|c|c|c|c|c|c|c|c|}
\hline \multirow{2}{*}{$\begin{array}{l}\text { Orchard } \\
\text { type }^{z}\end{array}$} & \multicolumn{6}{|c|}{ Macronutrients $\left(\mathrm{kg} \cdot \mathrm{ha}^{-1}\right)$} & \multicolumn{8}{|c|}{ Micronutrients $\left(\mathrm{kg} \cdot \mathrm{ha}^{-1}\right)$} \\
\hline & $\mathrm{pH}^{\mathrm{x}}$ & $\mathrm{CEC}^{y}$ & $\mathrm{P}$ & $\mathrm{K}$ & $\mathrm{Mg}$ & $\mathrm{Ca}$ & $\overline{\mathrm{Mn}}$ & $\mathrm{Fe}$ & $\mathrm{Zn}$ & $\mathrm{Cu}$ & $\mathrm{B}$ & $\mathrm{Ni}$ & Co & $\mathrm{Sn}$ \\
\hline $1^{\text {st }}$ gen. $-\mathrm{ME}$ & $6.2^{\mathrm{Ns}}$ & $6.3^{\mathrm{Ns}}$ & $95 \mathrm{a}$ & $174^{\mathrm{NS}}$ & $314^{\mathrm{Ns}}$ & $1215^{\mathrm{ss}}$ & $28 \mathrm{a}$ & $12 \mathrm{a}$ & $3 \mathrm{a}$ & $1.0 \mathrm{a}$ & $1.3^{\mathrm{Ns}}$ & $0.26 \mathrm{a}$ & $0.08^{\mathrm{Ns}}$ & $0.38 \mathrm{a}$ \\
\hline $1^{\text {st }}$ gen. $+\mathrm{ME}$ & 6.4 & 8.8 & $164 \mathrm{~b}$ & 226 & 295 & 1929 & $28 \mathrm{a}$ & $21 \mathrm{~b}$ & $48 \mathrm{~b}$ & $0.9 \mathrm{a}$ & 1.00 & $0.27 \mathrm{a}$ & 0.16 & $0.38 \mathrm{a}$ \\
\hline $2^{\text {nd }}$ gen. $+\mathrm{ME}$ & 6.2 & 7.1 & $146 \mathrm{~b}$ & 219 & 217 & 1700 & $58 \mathrm{~b}$ & $22 \mathrm{~b}$ & $73 \mathrm{c}$ & $2.0 \mathrm{~b}$ & 1.4 & $1.56 \mathrm{~b}$ & 0.15 & $0.92 \mathrm{~b}$ \\
\hline
\end{tabular}

${ }^{2}$ First generation $-\mathrm{ME}=$ first generation pecan orchard that is free of $\mathrm{ME}$ and is adjacent to a second generation orchard where transplants are exhibiting ME. First generation $+\mathrm{ME}=$ first generation pecan orchard in which young trees are exhibiting ME.

Second generation $+\mathrm{ME}=$ second generation pecan orchard in which transplants, at locations of missing trees, are exhibiting ME.

${ }^{\mathrm{y}}$ Cation exchange capacity (meq/100 g of soil).

${ }^{x}$ Satterthwaite $t$ test of treatment means. Means within a column followed by different letters are statistically different at the $P \leq 0.05$ leve

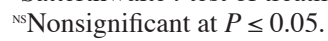


ME-prone sites. As noted above, $\mathrm{Cu}$ uptake was reduced by high $\mathrm{Zn}, \mathrm{P}$, or Ca (Tisdale et al., 1993). Orchards also are typically managed such that trees receive substantial $\mathrm{N}$ fertilizer just prior to budbreak. Nitrogen amounts typically range from 30 to $75 \mathrm{~kg} \cdot \mathrm{ha}^{-1}$. $\mathrm{N}$ applied to a low $\mathrm{Cu}$, high $\mathrm{Zn}-\mathrm{P}-\mathrm{Ca}$ soil is likely to further suppress the uptake of $\mathrm{Cu}$ (Robson and Reuter, 1981). It has been reported that the minimum soil elemental $\mathrm{Cu}$ concentration for pecan is $0.16 \mu \mathrm{g} \cdot \mathrm{g}^{-1}$ and the sufficiency range for $\mathrm{Cu}$ is between 6 to $30 \mu \mathrm{g} \cdot \mathrm{g}^{-1}$ (Smith, 1991). If ME is induced by a physiological deficiency of $\mathrm{Cu}$, then these standard values would necessarily vary depending upon soil chemistry and physiological availability within the plant.

Influence of planting at sites where pecan trees previously grew. The occurrence of $\mathrm{ME}$ by trees planted where a tree previously grew is illustrated in Fig. 5. Of 152 'Desirable' trees assessed in this second generation orchard, 64 trees exhibited ME symptoms. Of those exhibiting ME symptoms, 63 trees were on the exact sites of previous 'Success' trees and only one was growing at a location between preexisting trees. Thus, $84 \%$ of all trees planted on the old site exhibited ME whereas $1 \%$ of those planted between old sites exhibited ME. These data clearly illustrates a strong relationship between $\mathrm{ME}$ and the soil environment associated with previous trees. Soil characteristics were compared for locations within the same orchard that supported ME trees (those where 80-year-old 'Success' trees previously grew) and those not exhibiting ME (those planted mid-way between where 80-year-old 'Success' trees previously grew) (Table 4). Soil nutrient differences between the two sites were a 2-fold greater amount of $\mathrm{Zn}$ where there was ME, plus slightly greater levels of $\mathrm{Mn}, \mathrm{Ni}$, and $\mathrm{Sn}$. A similar, but less dramatic linkage is common when ME is exhibited by transplants in existing orchards. Thus, under certain conditions, ME is clearly a replant problem. When the root system of these trees is excavated and examined, there is often an abundance of dead or dying small roots. These roots often show severe galling by root-knot nematodes, but root-knot nematode damage is not always evident.

\section{Conclusion}

This study substantially expands on the types and forms of symptoms previously reported for ME. Failure to transmit ME via grafting indicates that the disorder is likely associated with a nutritional factor(s), rather than a biological agent. It is also evident that ME can be a soil related replant problem, having a high probability of occurring in certain orchards where transplants are established at sites where trees previously grew. However, the occurrence of severe ME is not limited to old pecan sites, but can also occasionally occur on new sites never before planted in pecan or other horticultural tree crops. In the latter case, occurrence is usually clustered within a certain location of the orchard possessing especially sandy soil.

The strong association between ME and the existence of a previous tree at the same physi-
Table 3. Comparison of soil micronutrient ratios between orchards exhibiting mouse-ear (ME) and adjacent orchards not exhibiting ME.

\begin{tabular}{lcccccc}
\hline Orchard type $^{z}$ & $\mathrm{Zn}: \mathrm{Cu}^{\mathrm{y}}$ & $\mathrm{Ni}: \mathrm{Cu}$ & $\mathrm{Co}: \mathrm{Ca}$ & $\mathrm{Mn}: \mathrm{Cu}$ & $\mathrm{Sn}: \mathrm{Cu}$ & $\mathrm{Zn}: \mathrm{Ni}$ \\
\hline $1^{\text {st }}$ generation $-\mathrm{ME}$ & $3 \mathrm{a}^{\mathrm{x}}$ & $0.30 \mathrm{a}$ & $0.10^{\text {Ns }}$ & $33^{\text {Ns }}$ & $0.44^{\text {Ns }}$ & $108 \mathrm{a}$ \\
$1^{\text {st }}$ generation $+\mathrm{ME}$ & $47 \mathrm{~b}$ & $0.21 \mathrm{a}$ & 0.06 & 36 & 0.54 & $338 \mathrm{~b}$ \\
$2^{\text {nd }}$ generation $+\mathrm{ME}$ & $52 \mathrm{~b}$ & $1.95 \mathrm{~b}$ & 0.17 & 55 & 0.65 & $108 \mathrm{a}$ \\
\hline
\end{tabular}

${ }^{2}$ First generation $-\mathrm{ME}=$ first generation pecan orchard that is free of ME and is adjacent to a second generation orchard where transplants are exhibiting ME. First generation $+\mathrm{ME}=$ first generation pecan orchard in which young trees are exhibiting ME. Second generation $+\mathrm{ME}=$ second generation pecan orchard in which transplants, at locations of missing trees, are exhibiting ME.

${ }^{y} \mathrm{Rate}$ of $\mathrm{Zn}$ to $\mathrm{Cu}$ after adjusting for cation exchange capacity (CEC) of the soil [i.e., (kg.ha- ${ }^{-1}$ of $\mathrm{Zn} / \mathrm{CEC}) /\left(\mathrm{kg} \cdot \mathrm{ha}^{-1}\right.$ of $\left.\left.\mathrm{Cu} / \mathrm{CEC}\right)\right]$.

${ }^{\mathrm{x}}$ Satterthwaite $t$ test of treatment means. Means within a column followed by the same letter are statistically different at the $P \leq 0.05$ level.

${ }^{\text {Ns }}$ Nonsignificant at $P \leq 0.05$ level

Table 4. Soil characteristics of a mouse-ear affected second-generation 'Desirable' orchard planted at the same site where an 80-year-old 'Success' orchard previously grew. Half of the newly planted 'Desirable' trees were at the exact location of pre-existing 'Success' trees (on previous site) and half were midway between pre-existing 'Success' trees (between trees).

\begin{tabular}{|c|c|c|c|c|c|c|c|c|c|c|c|c|c|c|}
\hline \multirow{2}{*}{$\begin{array}{l}\text { Transplant } \\
\text { location }^{z}\end{array}$} & \multirow[b]{2}{*}{$\mathrm{pH}$} & \multirow[b]{2}{*}{ CEC } & \multicolumn{4}{|c|}{ Macronutrients $\left(\mathrm{kg} \cdot \mathrm{ha}^{-1}\right)$} & \multicolumn{8}{|c|}{ Micronutrients $\left(\mathrm{kg} \cdot \mathrm{ha}^{-1}\right)$} \\
\hline & & & $\mathrm{P}$ & $\mathrm{K}$ & $\mathrm{Mg}$ & $\mathrm{Ca}$ & $\mathrm{B}$ & $\mathrm{Zn}$ & $\mathrm{Mn}$ & $\mathrm{Fe}$ & $\mathrm{Cu}$ & $\mathrm{Ni}$ & Co & $\mathrm{Sn}$ \\
\hline Previous site & $6.1^{y}$ & 8.4 & 205 & 323 & 224 & 1300 & 1.6 & 90 & 59 & 27 & 0.5 & 2.2 & 0.2 & 0.8 \\
\hline Between trees & 6.1 & 8.1 & 230 & 310 & 220 & 1258 & 1.5 & 52 & 46 & 31 & 0.6 & 1.7 & 0.2 & 0.6 \\
\hline Significance & NS & NS & NS & NS & NS & NS & NS & * & * & NS & NS & $*$ & NS & $*$ \\
\hline
\end{tabular}

${ }^{2}$ Transplants planted at exact site where a 80 -year-old 'Success' tree previously stood vs. planted mid-way between where 'Success' trees previously grew.

Ns, "Nonsignificant or significantly different at $P \leq 0.05$, respectively.

\begin{tabular}{|c|c|c|c|c|}
\hline \multirow[t]{2}{*}{$\ldots \bullet$} & $*$-ME & *-ME & *HE & $\boldsymbol{*}-\mathbf{N}$ \\
\hline & $\mathbf{N}$ & $\mathbf{N}$ & $\mathbf{N}$ & $\mathbf{N}$ \\
\hline \multirow[t]{2}{*}{$\ldots \odot$} & *-ME & $*-\mathrm{N}$ & *-ME & *-ME \\
\hline & $\mathbf{N}$ & $\mathbf{N}$ & $\mathbf{N}$ & $\mathbf{N}$ \\
\hline \multirow[t]{2}{*}{$\ldots \odot$} & $*$ *ME & *-ME & *-ME & $\boldsymbol{t}-\mathbf{N}$ \\
\hline & $\mathbf{N}$ & $\mathbf{N}$ & $\mathbf{N}$ & $\mathbf{N}$ \\
\hline \multirow[t]{2}{*}{$\ldots \bullet$} & $*$ *ME & $\boldsymbol{*}$-ME & *-ME & *t-ME \\
\hline & $\mathbf{N}$ & $\mathbf{N}$ & $\mathbf{N}$ & $\mathbf{N}$ \\
\hline \multirow[t]{2}{*}{$\ldots \bullet$} & *-ME & $\boldsymbol{*}-M E$ & $*-N$ & $*-N$ \\
\hline & $\mathbf{N}$ & $\mathbf{N}$ & $\mathbf{N}$ & $\mathbf{N}$ \\
\hline \multirow[t]{2}{*}{$\ldots \bullet$} & $*$ ME & $\boldsymbol{*}$-ME & *-ME & $*-N$ \\
\hline & $\mathbf{N}$ & $\mathbf{N}$ & $\mathbf{N}$ & $\mathbf{N}$ \\
\hline \multirow[t]{2}{*}{$\ldots \bullet$} & $*-M E$ & $\boldsymbol{*}$-ME & $\mathbf{*}-\mathbf{N}$ & $*-N$ \\
\hline & $\mathbf{N}$ & $\mathbf{N}$ & $\mathbf{N}$ & $\mathbf{N}$ \\
\hline \multirow[t]{2}{*}{$\ldots \bullet$} & *-ME & \#-ME & *-ME & $*-N$ \\
\hline & $\mathbf{N}$ & $\mathbf{N}$ & $\mathbf{N}$ & $\mathbf{N}$ \\
\hline \multirow[t]{2}{*}{$\ldots$} & *-ME & *-ME & + $\mathbf{H E}$ & $*-N$ \\
\hline & $\mathbf{N}$ & $\mathbf{N}$ & $\mathbf{N}$ & $\mathbf{N}$ \\
\hline \multirow[t]{2}{*}{$\ldots \bullet$} & *-ME & $\boldsymbol{*}$-ME & +ME & *-ME \\
\hline & $\mathbf{N}$ & $\mathbf{N}$ & $\mathbf{N}$ & $\mathbf{N}$ \\
\hline \multirow[t]{2}{*}{$\ldots \bullet$} & $*-N$ & $*$ *ME & $\boldsymbol{*}$-ME & $\boldsymbol{*}$-ME \\
\hline & $\mathbf{N}$ & $\mathbf{N}$ & $\mathbf{N}$ & $\mathbf{N}$ \\
\hline \multirow[t]{2}{*}{$\ldots \bullet$} & $\boldsymbol{*}-\mathbf{N}$ & $\boldsymbol{*}$-ME & $*-N$ & $\boldsymbol{*}-\mathbf{N}$ \\
\hline & $\mathbf{N}$ & $\mathbf{N}$ & $\mathbf{N}$ & $\mathbf{N}$ \\
\hline$\ldots \odot$ & $\boldsymbol{*}-\mathbf{N}$ & $\boldsymbol{*}$-ME & *-ME & $*-N$ \\
\hline
\end{tabular}

Fig. 5. The occurrence of mouse-ear in young 'Desirable' trees planted as a second generation orchard is illustrated. The previous orchard was comprised of $\approx 80$ year-old 'Success' trees that were under commercial management. Tree spacing in the old 'Success' trees was $18.3 \mathrm{~m} \times 18.3 \mathrm{~m}$, whereas in the new orchard it is $18.3 \mathrm{~m} \times 9.15 \mathrm{~m}$. Codes are as follows: $\bullet=$ existing orchard of 80 -year-old trees; $\mathbf{x}=$ location of preexisting 'Success' trees and where 'Desirable' trees were transplanted.; ME $=$ 'Desirable' trees exhibiting symptoms of the mouse-ear disorder; $\mathbf{N}=$ 'Desirable' trees exhibiting normal growth (i.e., no mouse-ear). 
cal site is evidence that it may potentially be induced or influenced by: 1) orchard management practices associated with the previous tree or orchard (fertilization, pest control, etc.); 2) soil borne pests (nematodes, fungi, bacteria, arthropods, etc.); or 3) autotoxic alleopathic factor(s) from the previous tree. The occurrence of ME at sites not previously planted with pecan is evidence that the autotoxic alleopathic explanation is likely invalid. The lack of a clear and consistent linkage between ME and the presence of any particular biological agent on root systems tends to discount "associated pests" as the primary causal factor(s), but does not exclude the possibility that a microorganism, such as nematodes, could substantially contribute to the severity of the problem. The sporadic occurrence of ME in first generation orchards and pronounced "replant" aspect of the problem at sites of previous trees and orchards, is evidence that ME is being induced by low availability of a soil micronutrient that is inherently low in certain soils or whose uptake and/or physiological availability is being suppressed by other nutrient elements. The longterm usage of N, P, Zn, Sn (via fungicides), and $\mathrm{Ca}$ at relatively high levels in many of the Gulf Coast Coastal Plain soils of the Southeastern Pecan Belt raises the possibility of complex nutrient element interactions that produce an imbalance of a key micronutrient element(s) in the tree at time of budbreak.

The inherently low level of available $\mathrm{Cu}$ in many Gulf Coast Coastal Plain soils, plus the ability of $\mathrm{Zn}, \mathrm{P}, \mathrm{N}, \mathrm{Sn}$, and Ca to influence $\mathrm{Cu}$ uptake and physiological availability (Tisdale et al., 1993), and high degree of similarity to physiological and morphological symptoms typical of $\mathrm{Cu}$ deficiency in other species (Kochian, 1991; Reuther, 1957; Robson and Reuter, 1981; Welch, 1995) leads the authors to hypothesize that a deficiency of physiologically available $\mathrm{Cu}$ at budbreak is the key causal factor for $\mathrm{ME}$ in pecan. It is also possible that other micronutrients, such as $\mathrm{Ni}$ or $\mathrm{Ca}$; which to varying degrees, exhibit certain soil, root uptake, intraplant translocation and mobility, and physiological characteristics similar to $\mathrm{Cu}$ (Kochian, 1991; Tisdale et al., 1993; Welch,
1995). The usual, but not absolute, association of root-knot nematode parasitism on roots with severely mouse-eared trees leads us to postulate that nematode feeding damage can be a substantial secondary contributor to ME (via reducing root uptake of key micronutrients on deficient sites or on sites with soil conditions that suppress availability or uptake of key micronutrients). These observations provide strong circumstantial evidence that ME is may be caused by a physiological deficiency of $\mathrm{Cu}$, or other transition group metal, and that, in certain situations, nematodes or may also be involved. Testing of this postulate will reveal critical insight into how to prevent and correct $\mathrm{ME}$ in pecan orchards.

\section{Literature Cited}

Gallaher, R.N. and J.B. Jones, Jr. 1976. Total extractable, and oxalate calcium and other elements in normal and mouse-ear pecan tree tissue. J. Amer. Soc. Hort. Sci. 101:692-696.

Gammon, N. and R.H. Sharpe. 1956. Mouse-ear: A manganese deficiency of pecans. Proc. Amer. Soc. Hort. Sci. 68:195-200.

Goff, W.D. and G.J. Keever. 1991. Omission of lime reduces mouse-ear symptoms in container-grown pecan trees. HortScience 26:383-386.

Graham, R.D. 1976. Anomalous water relations in copper-deficient wheat plants. Aust. J. Plant Physiol. 3:229-236.

Graham, R.D. 1981. Absorption of copper by plant roots, p. 141-163. In: J.F. Lonergan (ed.). Copper in soils and plants. Academic, New York.

Grauke, L.J., H.J. Morris, and J.G. Kowalczuk. 1983. Mouse-ear: A symptom of nutrient imbalance. Proc. Southeastern Pecan Growers Assn. 76: 141-147.

Harrison, S.J., N.W. Lepp, and D.A. Phipps. 1979. Uptake of copper by excised roots. IV. Copper uptake from complexed sources. Z. Pflanzenphysiol. 113:445-450.

Hedden, P., J. MacMillan, and B. Phinney. 1978. The metabolism of gibberellins. Ann. Rev. Plant Physiol. 28:149-192.

Keever, G.K.,W.D. Goff, and M.S. West. 1991. High dolomitic lime rates induce mouse-ear symptoms in container-grown pecan trees. HortScience 26: 1494-1495.

Kochian, L.V. 1991. Mechanisms of micronutrient uptake and translocation in plants, p. 229-296.
In: R.J. Luxmoore (ed.). Micronutrients in agriculture, $2^{\text {nd }}$ ed. Soil Sci. Soc. Amer., Madison, Wisc.

O'Barr, R.D., M.W. Smith, G. Taylor, and W. Goff. 1989. Pecan nutrition. p. 63-71. In: W.D. Goff, J.R. Mcvay, and W.S. Gazaway (eds.). Pecan production in the southeast: A guide for growers. Alabama Coop. Ext. Serv., ANR-459.

Rappaport, L. and D. Adams. 1978. Gibberellins: synthesis, compartmentalization and physiological process. Physiol. Trans. Royal Soc. London 284:521-539.

Reuther, W. 1957. Copper and soil fertility, p. 128-135, In: Soil, the yearbook of agriculture. U.S. Gov. Printing Office, Washington D.C.

Robson, A.D. and D.J. Reuter. 1981. Diagnosis of copper deficiency and toxicity, p. 287-312. In: J.F. Loneragan, A.D. Robson, and R.D. Graham (eds.). Copper in soils and plants. Proc. Golden Jubilee Intl. Symp., Murdoch Univ., Perth, Western Australia. Academic, Perth, Australia.

SAS Institute. 1990. SAS/Graph Software: Reference, version 6, vol. 2. SAS Inst., Cary N.C.

Smith, M.W. 1991. Pecan nutrition, p. 152-158. In: B.W. Wood and J.A. Payne (eds.). Pecan husbandry: Challenges and opportunities. U.S. Dept. of Agr., ARS-96.

Takahama, U. and O. Takayuki. 1994. The association of ascorbate and ascorbate oxidase in the apoplast with IAA-enhanced elongation of epicotyls from Vigna angularis. Plant Cell Physiol. 35:257-266.

Tisdale, S.L., W.L. Nelson, J.D. Beaton, and J.L. Havlin. 1993. Micronutrients and other beneficial elements in soils and fertilizer, p. 305-363. In: P.F. Corey (ed.). Soil fertility and fertilizers. Macmillan, New York.

Walker, C.D. and J. Webb. 1981. Copper in plants: Forms and behavior. p. 189-212. In: J.F. Loneragan, A.D. Robson, and R.D. Graham (eds.).Copper in soils and plants. Proc. Golden Jubilee Intl. Symp., Murdoch Univ., Perth, Western Australia. Academic, Perth, Australia.

Welch, R.M. 1995. Micronutrient nutrition of plants. Critical Rev. Plant Sci., 14:49-82.

Wood, B.W., C.C. Reilly, T. Cottrell, W. L. Tedders, and I. Yates. 2000. Bronzing of pecan foliage. J. Amer. Soc. Hort. Sci. 125:41-46.

Worley, R.E. 1979. Pecan cultivars differ in leaf elemental concentration of normal and mouse-ear leaf tissue. HortScience 14:51-52.

Zimmermann, M.H. and C.L. Brown. 1971. Secondary growth, p. 67-124. In: M.H.Zimmerman and C.L. Brown (eds.). Trees: Structure and function. Springer-Verlag, New York. 